壁式鉄筋コンクリート構造建物の履歴減衰と変形分布に関する研究 STUDY ON HYSTERETIC DAMPING AND DEFORMATION PROFILE ALONG
THE HEIGHT OF REINFORCED CONCRETE BOX-SHAPED WALL BUILDINGS

\author{
平石久廣*1, 本橋博明*2, 木村 匡*3 \\ Hisahiro HIRAISHI, Hiroaki MOTOHASHI and Tadashi KIMURA
}

\begin{abstract}
This paper shows the results of examinations of the hysteretic damping and the deformation profile along the height of full-scale test results of reinforced concrete box-shaped wall structures. The equivalent estimation method of the hysteretic damping is proposed and examined for the test hysteretic curves, which had not stationary loop. Then, the calculated hysteretic damping ratio of reinforced concrete box-shaped wall structures is discussed and summarized. The paper also concludes that the deformation profile along the height of a structure is estimated by considering appropriately the rotationed deformation in addition to shear and flexural deformations, and deterioration in flexural rigidity of simplified fish-born type models.
\end{abstract}

Keywords : Reinforced Concrete, Box-Shaped Wall Buildings, Seismic Performance Evaluation, Hysteretic Damping, Deformation Profile

鉄筋コンクリート造、壁式 RC 造、性能評価、履歴减衰、変形分布

1. 序

我が国の集合住宅を代表する一つの構造形式である壁式鉄筋コン クリート構造の設計規準 1 は、建築物が整形な形状を有することを 前提とし、壁量・壁配置等の多くの仕様書的な構造規定から成り立 っている。このため、不規則な開口を有し、構造解析という観点か らは極めて複雑な形状であるにもかかわらず、壁式鉄筋コンクリー 卜造（以下、壁式 RC 造と略す）の設計においては、複雑な構造計算 を行うことなく設計を容易に行える半面、詳細な構造的な検討を行 わないことから、設計された建築物の構造的な性能は極めて分かり づらいものとなっている。

このように設計が容易な反面、詳細な構造的な検討を行わないこと は、壁式 $\mathrm{RC}$ 造の発展において大きな利点であり、一方ではその発展 の妨げともなってきた。すなわち、設計規準が仕様書的な規定で定 められていることが、戦後の驚異的とも言える壁式 RC 造の普及の一 つの要因であった半面、構造性能の評価に対する必要性を希薄なも のとし、結果として、壁式 RC 造の新しい形態の追求やプランの自由 化を阻害する大きな要因ともなってきた。
従って、現在、その普及に陰りが見られる壁式 RC 造の建設をさら に促進するためには、簡便な設計法という利点はそれなりに保持し つつも、平面的、立体的により自由度の高い壁式 $R C$ 造にも適用可能 な性能評価、特に耐震性能の評価に基づく設計規準の確立が必要で あると考えられる。この耐震性能の評価については、近年、性能設 計への要求に答えるべく種々の方法が提示され、2000 年の建築基準 法の改定においては、等価線形化法による限界耐力計算が新たに導 入されている。

本論文は、以上のような背景及び観点から、壁式 RC 造の耐震性 能評価のため、等価線形化法で重要な因子である履歴减衰定数と建 築物の高さ方向の変形分布について既往の実大実験結果 $\left.{ }^{2)} \sim 5\right)$ の検 討を行った。减衰定数の評価では、壁式 RC 造の実大実験において載 荷の多数回の繰り返しがほとんど行われていないことから、一回の 繰り返しでも減衰定数が算定可能な方法を提示し、その方法に基づ いて壁式 RC 造の減衰定数の評価を行った。また、変形分布につい ては簡便な算定方法を意図し、魚骨型のモデルに置換した方法を用 いて行った。

\footnotetext{
*1 明治大学理工学部建築学科 教授 $\cdot$ 工博 (独立行政法人建勧研究所 客員研究員)

*2 明治大学大学院理工学研究科建築学専攻

*3 都市整備公団技術監理部設計課

Prof., Dept. of Architecture, Science and Technology, Meiji Univ., Dr. Eng. (Visiting Research Fellow, Building Research Institute)

Graduate Student, Graduate School of Science and Technology, Meiji Univ.

Technical Administration Department, Design Division, Urban Development Corporation
} 
なお、壁式 $R C$ 造の減衰定数については、振動実験結果や常時微動の 測定から減衰定数の值を報告したもの例えば 2) 6) があるが、いずれも 弾性域における減衰定数で、塑性域での履歷减衰定数についてまと められたものはない。また、高さ方向の変形分布については個々の 実大実験について検討した報告はあるものの判えば5)、これらは実験解 析を主眼として行われており、一般論的なことについては定性的な 評価すらなされていない。

\section{2. 実大実験結果の概要}

検討を行った資料は、（旧）日本住宅公団の委託を受けて（旧）建 設省建築研究所が行った、壁式 RC 造の実大実験 4(体 2)314)5) である。 更に詳細なデーターは都市基盤整備公団総合試験所に保管されてい た、これらの実験報告書によった。本研究で検討に用いた壁式 RC 造 の実大実験 4 体の試験体概要を表 1 にそれらの平面図・立面図・荷 重変形曲線を図 1 9 亿示す。以下では、この 4 件の実大実験を表 1 のように $5 \mathrm{FW} 1 ， 5 \mathrm{FW} 2 、 8 \mathrm{FW} 3 、 8 \mathrm{FW} 4$ と呼ぶ。なお $5 \mathrm{FWl}$ の 実験は、現場打 5 階建て壁式 RC 造建物の合理化を図る目的で行われ た実験であり、破壊形状は 1 階耐力壁のせん断破壊である。 $5 \mathrm{~F} \mathrm{W2}$ の実験は、丘陵地に立つ壁式 $\mathrm{RC}$ 造建物の性状把握を目的とした実験 であり、破壊形状は 1 階耐力壁のせん断破壊である。8F W3 の実験 は、8 階建て壁式 RC 造建物の実現を目的とした害験であり、破壊形 状は大変形時における壁梁のせん断破壊である。 $8 \mathrm{FW} 4$ の実験は、8 階建て壁式 RC 造建物の耐震安全性の検討を目的とした実験であり、 破壊形状は短スパン壁梁と耐力壁の曲げ破壊である。また、 $5 \mathrm{~F} \mathrm{W1}$ 及び $5 \mathrm{FW} 2$ の 5 階建ての壁式 RC 造を想定した実大実験（以下 $5 \mathrm{~F}$ $\mathrm{W}$ と略す) の外力分布は等分布加力で、 $8 \mathrm{FW} 3$ 及び $8 \mathrm{FW} 4$ の 8 階建 ての壁式 RC 造を想定した下部数層の実大実験（以下 $8 \mathrm{FW}$ と略す） においては逆三角形分布で載荷が行われている。

\section{表 1 壁式 RC 造の実大実験結果の概要}

\begin{tabular}{|c|c|c|c|c|}
\hline 実緊名 & 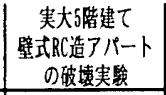 & 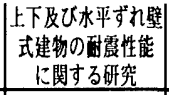 & \begin{tabular}{|l} 
睍場打58陼建 \\
下部4層実大実駼
\end{tabular} & 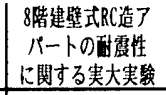 \\
\hline 䧄稿 & $5 F \mathrm{FI}$ & 5FP2 & $8 \mathrm{PF}_{3}$ & $8 F$ Fi4 \\
\hline 実䁂年次 & 1968 & 1970 & 1972 & 1978 \\
\hline 実剘目的 & 合理化 & 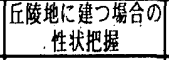 & 壁式8階建ての実其 & 䑀式8階建ての実現 \\
\hline 外力分布 & 等分布加力 & 等分布加力 & 逆三角形分布 & 逆三角形分布 \\
\hline 建物栺数 (実陭の陼数) & $5(5)$ & $5(5)$ & $8(4)$ & $8(5)$ \\
\hline 勀力壁厚 (回) & 150 & 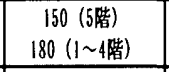 & $\begin{array}{l}300 \text { (3 4階) } \\
350(1 \sim 2 \text { 㳻) } \\
\end{array}$ & 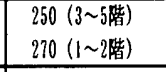 \\
\hline 壁量 $\left(\mathrm{m} / \mathbb{m}^{2}\right)$ & 120 & 150 & 66.0 & 120 \\
\hline 酎力壁の民筋 & 弾飳 & 複配筋 & 複酷箶 & 複区䇥 \\
\hline 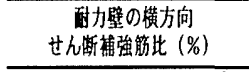 & 0.25 & 0.28 & 1.13 & \begin{tabular}{|l}
$0.47(1 \sim 2 \mathrm{~F}), 0.37(3)$ \\
$\sim 4 \mathrm{~F}), 0.26(5 \mathrm{~F})$ \\
\end{tabular} \\
\hline コンクリート雚度 $\left(\mathrm{N} / \mathrm{m}^{\mathrm{n}}\right)^{2}$ & 230 & 230 & 210 & $240 \sim 280$ \\
\hline $\begin{array}{l}\tau_{0}: C_{0}=0.20 \text { 時の平坸 } \\
\text { せん断底力度 }\left(\mathrm{N} / \mathrm{m}^{2}\right) \\
\end{array}$ & 49.0 & 41.0 & 69.0 & 58.0 \\
\hline 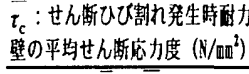 & 11.0 & 13.0 & 20.7 & 11.1 \\
\hline $\bar{t}_{\mathrm{c}} / \overline{\tau_{0}}$ & 21.0 & 21.6 & 31.0 & 22.8 \\
\hline 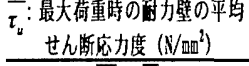 & 23.0 & 32.0 & 30.0 & 19.0 \\
\hline$\overline{\tau_{u}} / \overline{\tau_{0}}$ & 7.1 & 7.3 & 22.0 & 10.0 \\
\hline 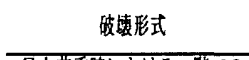 & 䣦力壁の世ん断破溒 & 辞力壁のせ九断政域 & 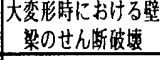 & 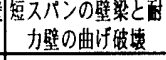 \\
\hline 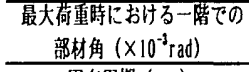 & 71.0 & 73.0 & 22.0 & 10.0 \\
\hline 固有周䀧 (sec) & $0.15 \sim 0.49$ & $0.15 \sim 0.46$ & $0.14 \sim 0.28$ & 0.229 \\
\hline
\end{tabular}
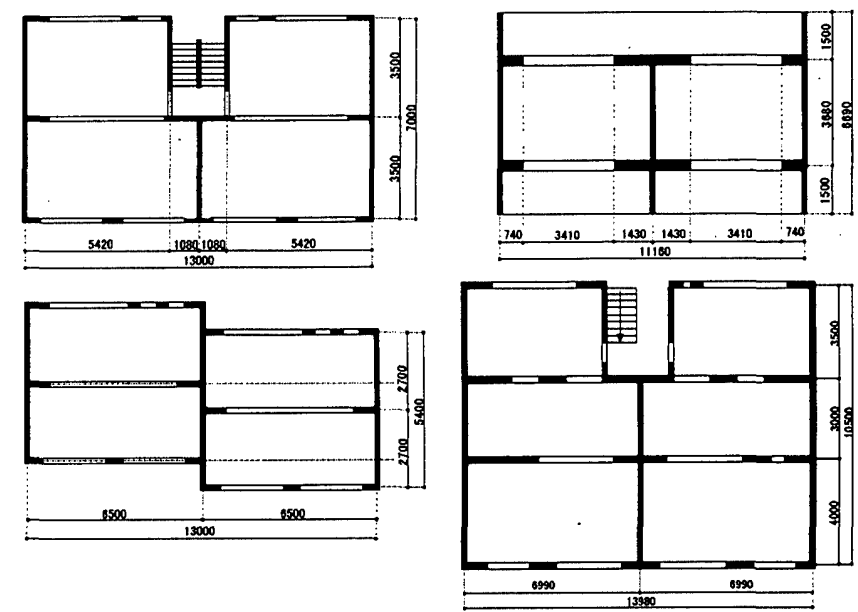

図 1 実験平面図（左上 $5 \mathrm{FW1}$ 、左下 $5 \mathrm{FW2}$ 、右上 $8 \mathrm{FW} 3$, 右下 $8 \mathrm{FW4}$ )
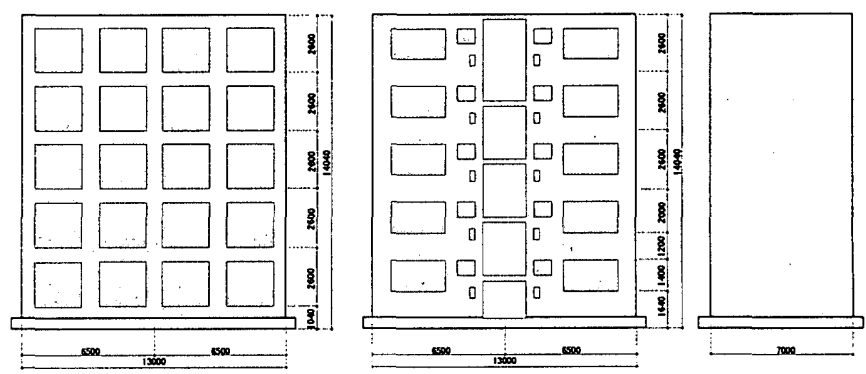

図 $25 \mathrm{FW} 1$ 立面図（左 南側、中 北側、右 東側）

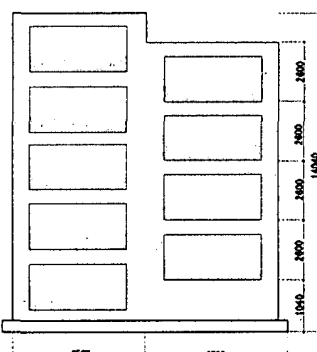

図 $35 \mathrm{~F} \mathrm{W2}$ 立面図
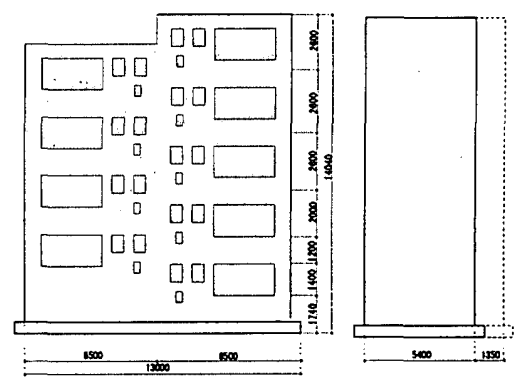

(側)
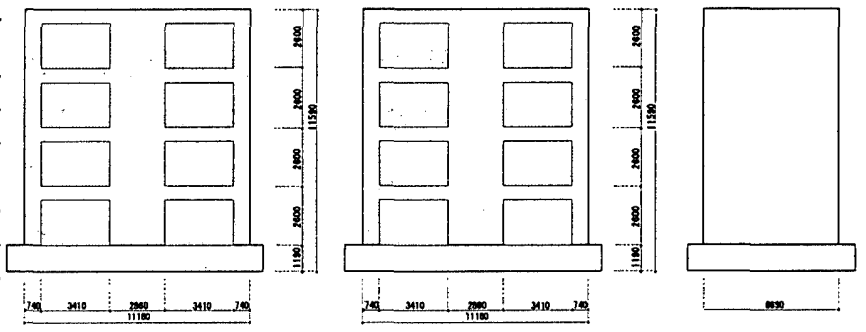

図 4 ８F W3 立面図（左 南側、中 北側、右 東側）

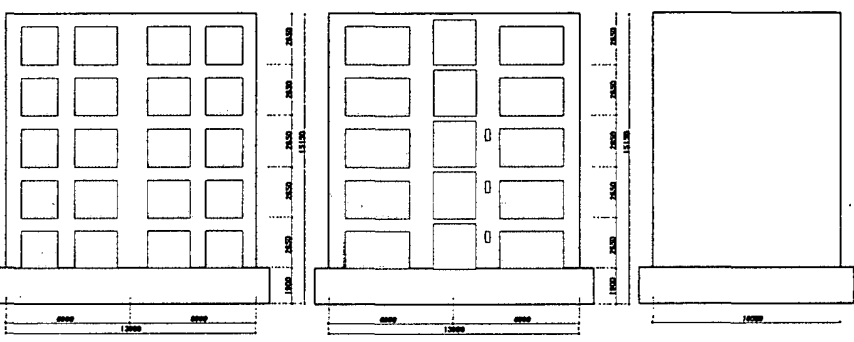

図 58 FW4 立面図（左 南側、中 北側、右 東側） 

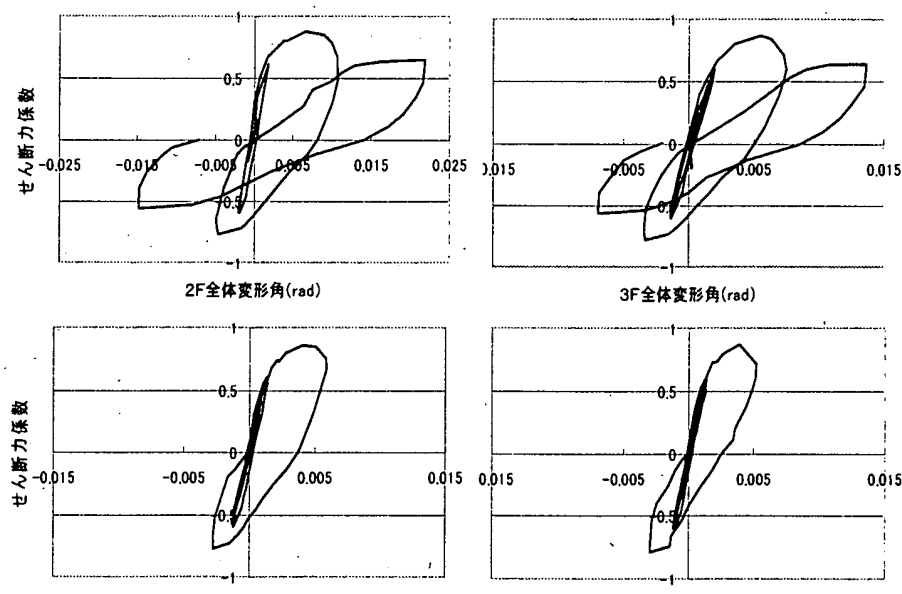

4F全体索形角(rad)

SF全体变形角(rad)

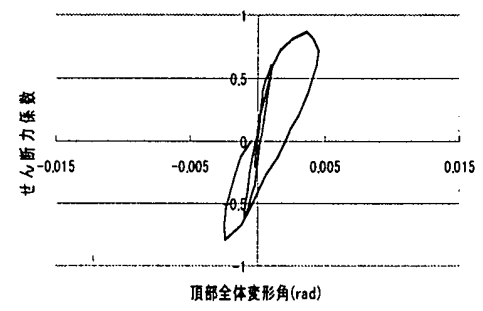

図 $65 F$ W 1 の荷重一变形曲線
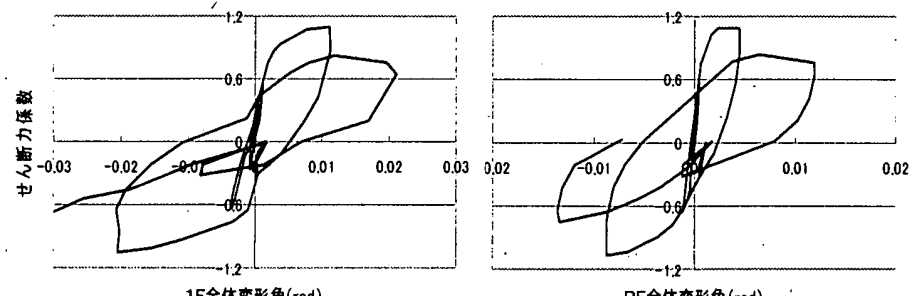

図 $75 F$ W2 の荷重一变形曲線
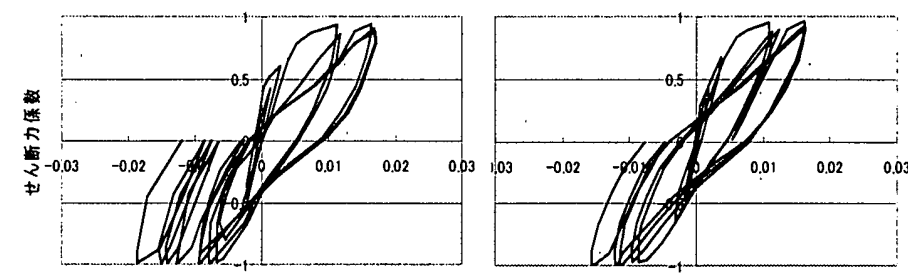

$2 \mathrm{~F}$ 全体变形角( $\mathrm{rad})$

3F全本变形角( $\mathrm{rad})$

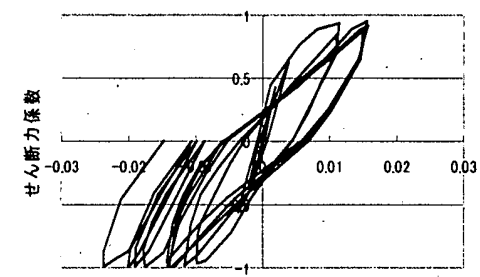

4F全体交形角(rad)

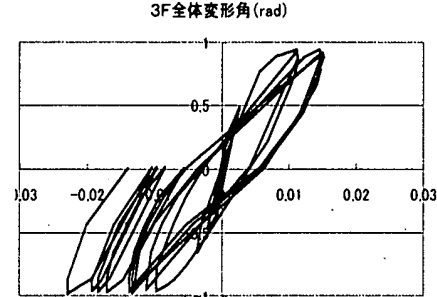

$\mathrm{RF}$ 全体麦形角 $(\mathrm{rad})$

図 8 8FW3 の荷重一変形曲線

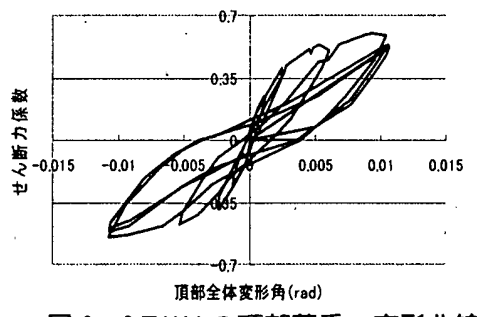

図 98 F W4 の頂部荷重一変形曲線

\section{3. 履歴減衰の算定}

3.1 定常ループから履歴減衰を求める方法

定常振幅時における荷重一変形関係の概念図と履歴減衰定数の算 定式を図 10 および(1)式に示す。ただし、既往の実験では、同一変 位を目指した荷重サイクルにおいて正荷重時之負荷重時でのピーク 時での荷重と変形がかなり異なる（図 6〜図 9 参照)。このため(1) 式の分母の計算に用いる荷重と変位は、サイクルピーク時の荷重、 変位の平均値として算定した。この分母の取り扱いに関しては以降 の算定においても同様とする。

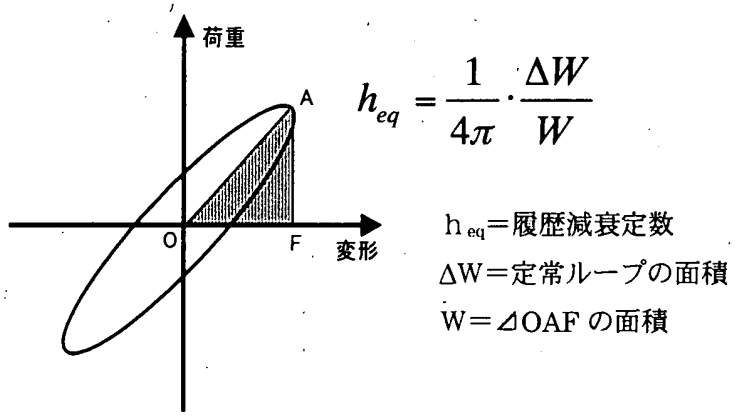

図 10 履歴特性の概念図

4.2 ループ上側から履歴減衰を求める方法

繰り返しにおける履歴特性の模擬図を図 11 に示す。本研究では、 既往の実大実験のように図中の濃い灰色で表す定常ループが得られ ていない場合、薄い灰色で示した 1 回繰り返しループの上側の面積 を 2 倍することで定常ループの面積を表すこととする。ここで上側 の面積とは、図 12 のように模式化した場合の $\triangle \mathrm{A} C \mathrm{D}$ の面積のこと であり、この面積を 2 倍することで（1）式の $\Delta \mathrm{W}$ が与えられるもの とし、履歴隇衰定数の一次近似値を求めることとした。

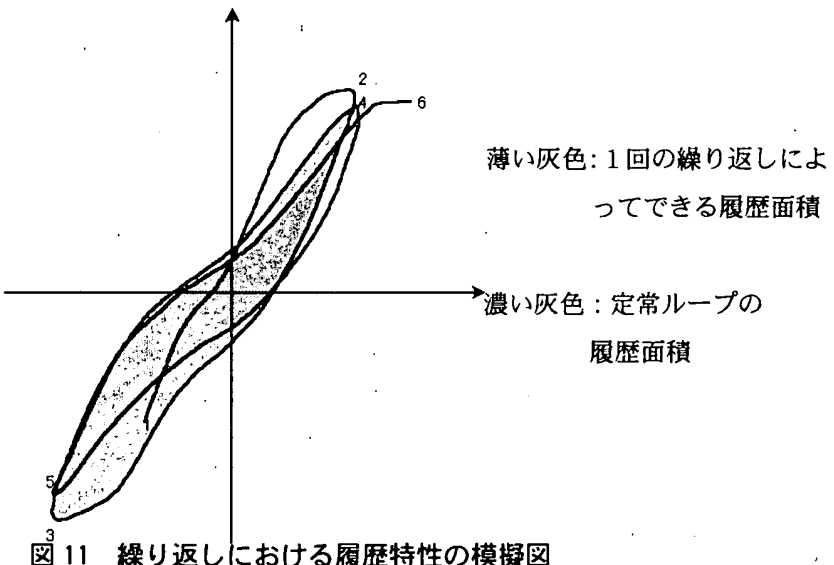

なお、このように片側ループから履歴減衰定数を求める場合、正 負のピーク時の変形が異なるとループ上側とループ下側の面積には 差が生じる。そこで本論では、ループ上側の面積を 2 倍したものを 補正することにより、ループ全体の面積を表しうるような補正係数 $\beta$ を用い、最終的に履歷減衰定数の近似值（以下、換算履歴減衰定 数と呼ぶ）を求めた。

以下に補正係数の算定方法を、図 13 に正負荷重ピーク時の変形が 異なる場合の簡略図を示す。 


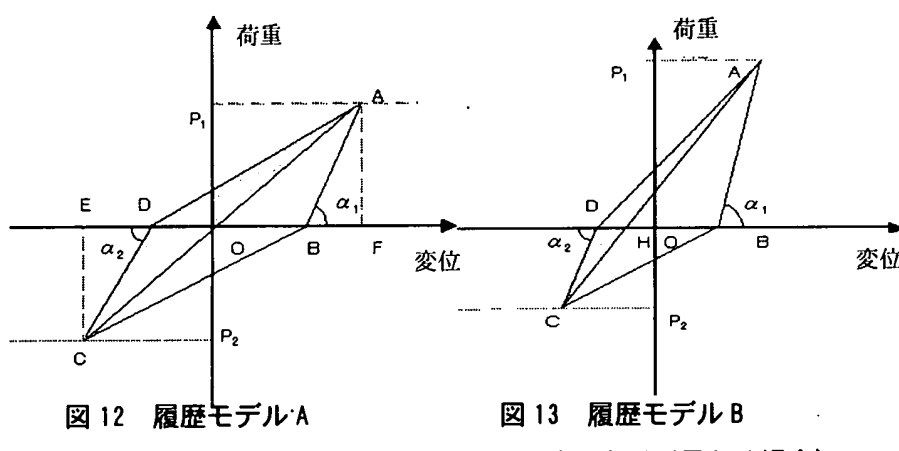

\section{・補正係数 $\beta$ の算定方法}

図 13 において $\alpha_{1}=\alpha_{2}=\alpha$ と仮定する。

$\triangle \mathrm{A} C \mathrm{D}$ およびA B CDの面積は以下のようになる。

$$
\begin{aligned}
& \triangle \mathrm{ACD}=\mathrm{DH} \times\left(\mathrm{P}_{1}+\mathrm{P}_{2}\right) / 2 \\
& \mathrm{ABCD}=\mathrm{DB} \times\left(\mathrm{P}_{1}+\mathrm{P}_{2}\right) / 2
\end{aligned}
$$

よって、補正係数 $\beta$ は、式（4）のように表すことができる。

$$
\begin{aligned}
\beta & =\mathrm{ABCD} /(2 \times \triangle \mathrm{ACD}) \\
& =\mathrm{DB} / 2 \mathrm{DH}
\end{aligned}
$$

3.3 定常ループとの比較・検討

図 14、図 15 に、8F W3、8F W4 の実験の変形一定時の定常ルー プから求めた履歴減衰定数と上側ループから算定した履歴減衰定数 の一次近似值と、それに補正係数を乗じた換算履歴減衰定数を示す。 なお、参考として下側のループから算定した履歷減衰定数の一次近 似値、換算履歷減衰定数を白抜きで図中に示す。図中の横軸の加力 サイクルは、変形角 $1 / 100$ での変形一定時における、1 回目の繰り返 しサイクルの正加力時、負加力時、2 回目サイクルの正加力時、負加 力時、 3 回目サイクルの正加力時をそれぞれ 1,2,3,4,5 と示している。

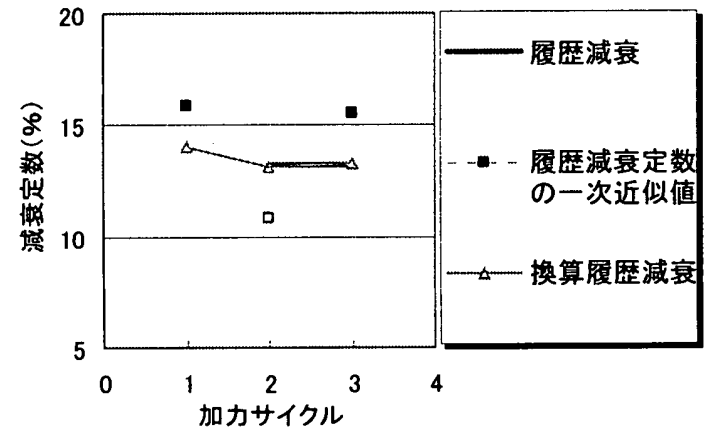

図 $148 F$ W3 の变形一定時の隇衰定数

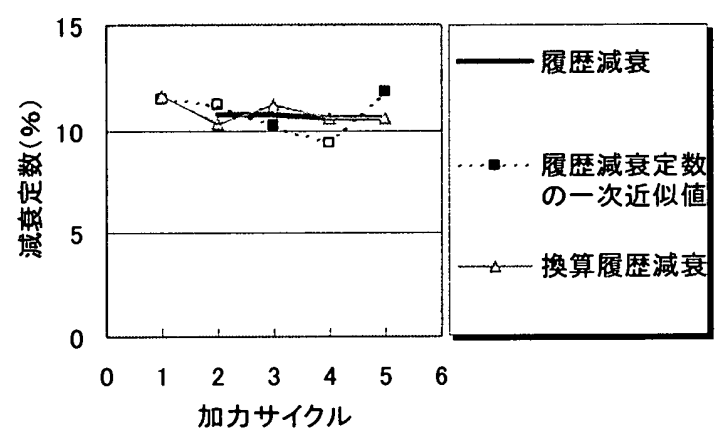

図 $158 F$ W4 の变形一定時の減衰定数

図 14、図 15 より両実験とも履歴減衰定数の一次近似值に補正係数 を乗じた換算履歴減衰定数は実験結果と良い対応を示している。以
上より履歴減衰定数の値を、一回の繰り返しループからでも本算定 方法でかなり精確に算定できるといえる。

\section{4 壁式 RC 造の滅衰定数}

各実大実呀の减衰定数一変形角関係を図 16 に示す。ここで、減衰 定数は荷重履歴が 2 回以上繰り返して定常ループが得られている履 歴からは履歴減衰定数を、定常ループが得られていない場合には換 算履歷减衰定数を算定したものを示す。壁式 $\mathrm{RC}$ 造の安全限界時の全 体変形角はおよそ $1 / 200 \sim 1 / 100$ と考えられ、その安全限界時近傍で の履歴減衰定数は、図からおおむね $10 \%$ 以上期待できるといえる。

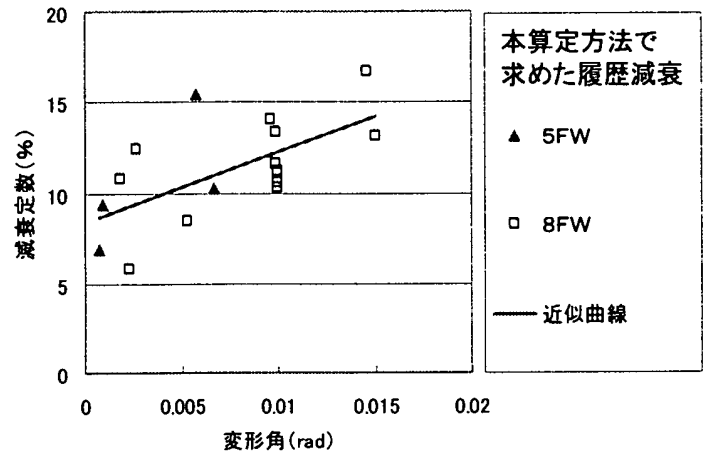

4. 变形分布の検討

図 16 隇衰定数一变形角図

\section{1 モデル化の方法}

変形分布算定のため、実大実験の建物を簡便な魚骨型モテルに置 換した。その際、同一㦿レベルにある節点の水平変位・節点回転角 はすべて等しいと仮定し、魚骨柱の弾性剛性 $\left(\overline{K_{B i}}\right)$ を元の骨組みの 層を構成するすべての壁の弾性剛性の和 $\left(\sum K_{\mathrm{ci}}\right)$ とした。また、魚骨 梁 $\left(\overline{K_{C i}}\right)$ は魚骨柱の嗍体回転を林レベルで拘束するばねとして考え、 元の骨組みの層を構成するすべての梁の弾性剛性の和 $\left(\sum K_{\mathbf{a}}\right)$ とし た。（（5）式、（6）式参照。) なお、反曲点高さ比は、魚骨梁、魚骨 柱の剛比から D 值法 ${ }^{8)}$ を用いて算定した。

$$
\begin{aligned}
& \overline{K_{c i}}=\sum K_{c i} \\
& \overline{K_{B i}}=\sum K_{B i}
\end{aligned}
$$

\section{2 損偒限界時の変形分布の検討}

損傷限界時の変形分布について、本算定方法の有効性を検討する。 なお、実験による水平変位の測定がスラブ位置であるため、以下で の水平変位もスラブ位置で表す。また、変形成分はせん断変形 $\left(\delta_{s}\right)$ 、 曲げ変形 $\left(\delta_{\mathrm{b}}\right)$ 、およびそれによる剛体回転による変形（以下、回 転変形 $\left(\delta_{\mathrm{r}}\right)$ と略す) を考虑した。ここで、回転変形は層ごとに部 材を定義し、壁脚部の回転角による壁のクリアスパン間の変形と各 層の壁上部に連なる梁剛域部の回転角による変形の和とする。なお、 梁と柱の接合部分は剛としていることから梁に連なる柱の当該階の 梁下端位置の回転角はスラブ位置の回転角と同じになり、梁成に相 当する部分ではこの回転角に応じた回転変形のみを生じる。回転変 形の算定式を（7）、（8）式に示す。

$$
\begin{aligned}
& \Delta \delta_{r i}=\theta_{r i-1} \cdot h_{i}+\theta_{r i} \cdot D \\
& \delta_{r i}=\delta_{r i-1}+\Delta \delta_{r i} \\
& \Delta \delta_{\mathrm{ri}}: \text { 当該階の回転変形の増分 } \\
& \theta_{\mathrm{ri}} \text { : 当該階の水平変位を表わすスラブ位置の回転角 } \\
& \mathrm{h}: \text { 階高 } \\
& \quad \mathrm{D}: \text { 梁成 } \quad \Delta \delta_{\mathrm{ri}}: \text { 当該階の回転変形 }
\end{aligned}
$$


損傷限界時における変形成分の解析值を図 17 に、変形分布を図 18 に示す。ここで、本論文では耐力壁にせん断ひび割れが発生した 時点を損傷限界時はと設定した。また、変形分布は建物頂部の全体 変形に対する各階の全体変形の比を表す。一般に、壁式 RC 造ではせ ん断変形が卓越するとされているが、図 17 より損傷限界時において は、曲げ変形や回転変形の全体変形に占める割合が大きい。従って、 壁式 RC 造の変形を評価する際には、せん断変形だけでなく曲げ及び それによる回転変形を適切に考慮することが重要であると言える。 また、図 18 において実験值及び解析值の変形分布がほほ一致するこ とから、損傷限界時の変形分布をせん断変形だけでなく曲げ及びそ れによる回転変形を考虑する魚骨型モデルでおおむね表すことが出 来ると言える。表 2 に各実験建物を、以上の変形分布を用いて一質 点系に縮約して求めた有効質量を示す。表より有効質量の実験值及 び解析值の差は $3 \%$ 以内であり、このことからも求めた変形分布が適 切に評価されていることが分かる。
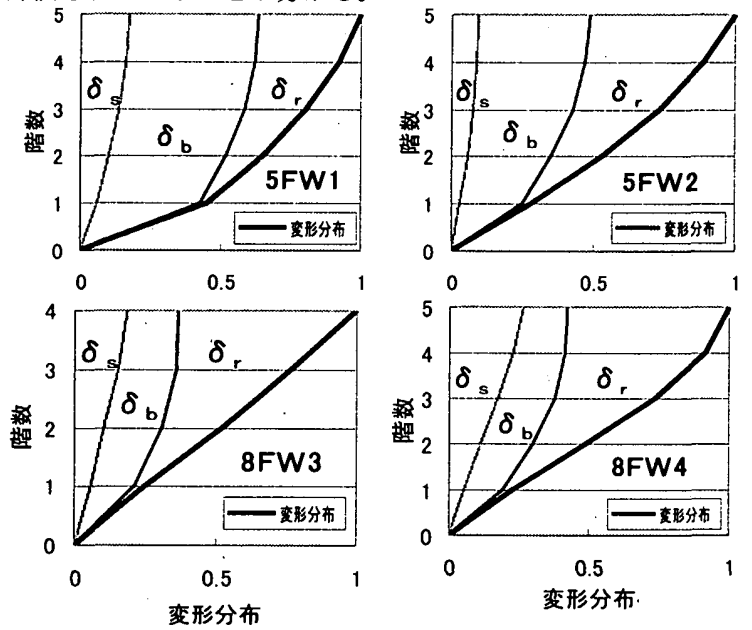

図 17 損傷限界時の変形成分
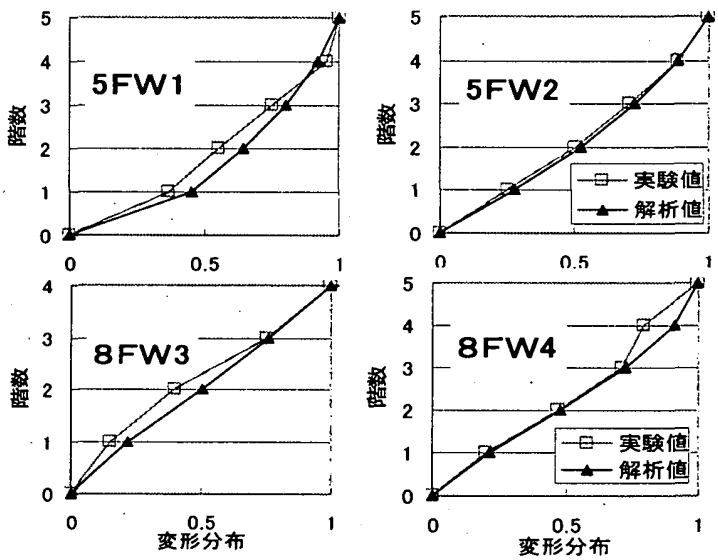

図 18 損偒限界時の変形分布

表 2 損傷限界時の有効質量

\begin{tabular}{c|c|c|c} 
損侮限界時 & exp $\mathrm{Mu}(\mathrm{kN})$ & $\mathrm{cal} \mathrm{Mu}(\mathrm{kN})$ & $\exp ^{\mathrm{Mu}} /{ }_{\mathrm{cal}} \mathrm{Mu}$ \\
\hline 5FW1 & 2825 & 2942 & 1.04 \\
\hline 5FW2 & 3649 & 3649 & 1.00 \\
\hline 8FW3 & 6961 & 7249 & 1.04 \\
\hline 8FW4 & 22756 & 23479 & 1.03
\end{tabular}

\section{3 最大耐力時の变形分布の検討}

最大耐力時以降の実大実験のデーターが少ないため、塑性域の変 形分布算定の方法を最大耐力時の変形分布について検討した。ここ で、耐力壁の剛性は、塑性域においてせん断剛性のみ低下すると仮
定し、曲げ・回転剛性は弾性とした変形成分の和で各層の復元力特 性を作成した。具体的には、せん断力に対しては（9）～(10) 式のよ うに元の骨組みの層を構成するすべての壁の耐力の和を用いた復元 力特性を作成し、第三勾配は弾性剛性の $3 \%$ としたトリリニアで評価 した。また、変形分布の解析值は最大層間変形の実験値が最大耐力 時の実験値と一致する時のものとした。

一方、最大耐力時において梁の剛性低下は無視すること出来ない ことが実験結果より容易に想定される。そこで、本検討では梁の用 性低下を仮定し、梁の用性を 0.5 0.25,0.125に低下させたそれぞれ モデルの層間変形角の分布と実験値とを比較する事で剛性低下の適 正値について検討を行った。

第一折れ点（せん断ひびわれ点）

$$
\begin{aligned}
& \sum Q_{c}=\sum\left\{\left({ }_{s} \tau_{c r} \cdot \gamma_{c} \cdot t_{w} \cdot l\right) / k_{s}\right\} \\
& \gamma_{c}=\frac{\sum Q_{c} \cdot \kappa}{\gamma \cdot G_{c} \cdot \sum A_{w}} \\
& \text { ここで、 } \quad{ }_{s} \tau_{c r}=\sqrt{\left(\sigma_{r}^{2}+\sigma_{t} \sigma_{0}\right)} \quad \sigma_{t}=0.313 \text {. }
\end{aligned}
$$

$\sum Q_{c}:$ 魚骨柱せん断ひび割れ強度 $\left(\mathrm{N} / \mathrm{mm}^{2}\right)$

$\sigma_{t}:$ コンクリート引張強度 $\left(\mathrm{N} / \mathrm{mm}^{2}\right)$

$\gamma_{c}:$ せん断変形角

$\mathrm{G}_{\mathrm{C}}$ : コンクリートせん断弾性剛性 $\left(\mathrm{N} / \mathrm{mm}^{2}\right)$

$\sigma_{0}:$ 軸方向応力度 $\left(\mathrm{N} / \mathrm{mm}^{2}\right) \quad r$ : 開口低减率 $(=1)$

$\sum A_{w}$ : 壁断面積 $\left(\mathrm{mm}^{2}\right) \quad \mathrm{K}$ : 形状俰数 $(=1.5)$

第 2 折れ点（せん断終局点）

$$
\begin{aligned}
& \sum Q_{u}=\sum\left[\left\{\frac{0.068 p_{t}^{0.2}\left(\sigma_{B}+17.6\right)}{\sqrt{M /\left(Q \cdot l_{w}\right)+0.12}}+0.85 \sqrt{p_{w} \cdot \sigma_{w y}}+0.1 \sigma_{0}\right\} b_{e} \cdot j\right] \\
& p_{t}=100 a_{g} /\left(b_{e} \cdot l_{w}^{\prime}\right) \\
& \gamma_{u}=\frac{4}{1000} .
\end{aligned}
$$$$
\sum Q_{u}: \text { 魚骨柱せん断終局強度 }\left(\mathrm{N} / \mathrm{mm}^{2}\right)
$$$$
\begin{aligned}
& \gamma_{u}: \text { せん断終局変形角 } \quad M /\left(Q \cdot l_{w}\right) \text { : シヤスパン比 } \\
& j: \text { 応力中心間距離 }(\mathrm{mm}) \quad p_{w}: \text { 壁板横筋比 (\%) }
\end{aligned}
$$

図 19 に最大耐力時における各階の層間変形角を示す。解析値は梁 の剛性をそれぞれ 0.5 から 0.125 まで低下させた層間変形角である。 ここで、8F W4 の実験の破壊形状は明らかな耐力壁の曲け破壊であ り、曲げを弾性とする本方法では変形を適切に評価出来ないので検
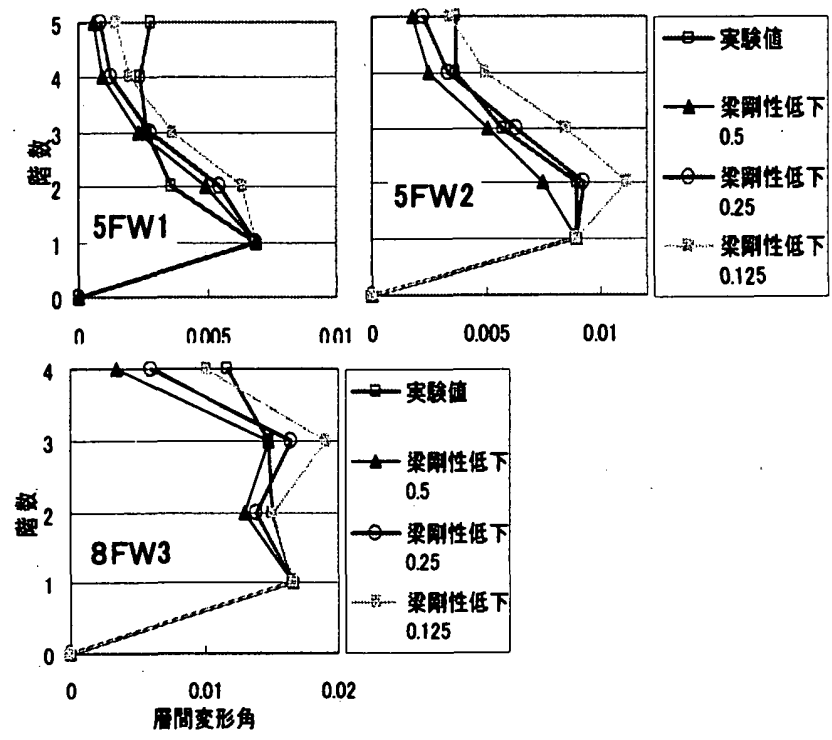

図 19 最大耐力時の層間变形角 
討から省いている。梁の剛性を低下させると下層の反曲点高さ比が 大きくなり、その結果として上層階の回転変形が大きくなり層間変 形が大きくなっている。しかし、剛性低下の割合によらず実験値と ほほ等しい層間変形の分布を表すことができ、梁の剛性をおよそ 0.25 に低下させるとより実験值と一致する。図 20 に梁の剛性低下を 0.25 とした最大耐力時の変形成分を、図 21 には変形分布を示す。最 大耐力時の変形成分は、耐力壁のせん断ひび割れ、降伏の発生によ り、損傷限界時に比べてせん断変形の影響が大きくなっていること が分かる。表 3 に以上の変形分布を用いて算定した有効一質量を示す。 表のように有効質量の実験值及び解析値の差は $5 \%$ 以内であり、損傷 限界時同様良い対応を示している。このことからも求めた変形分布 が適切に評価されていることが分かる。

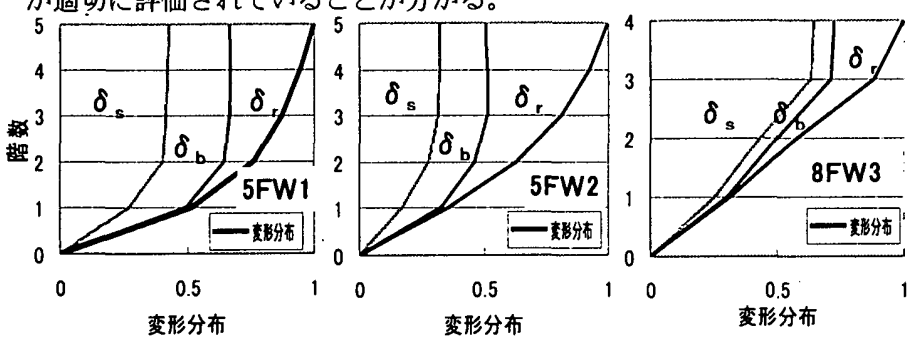

図 20 最大耐力時の变形成分

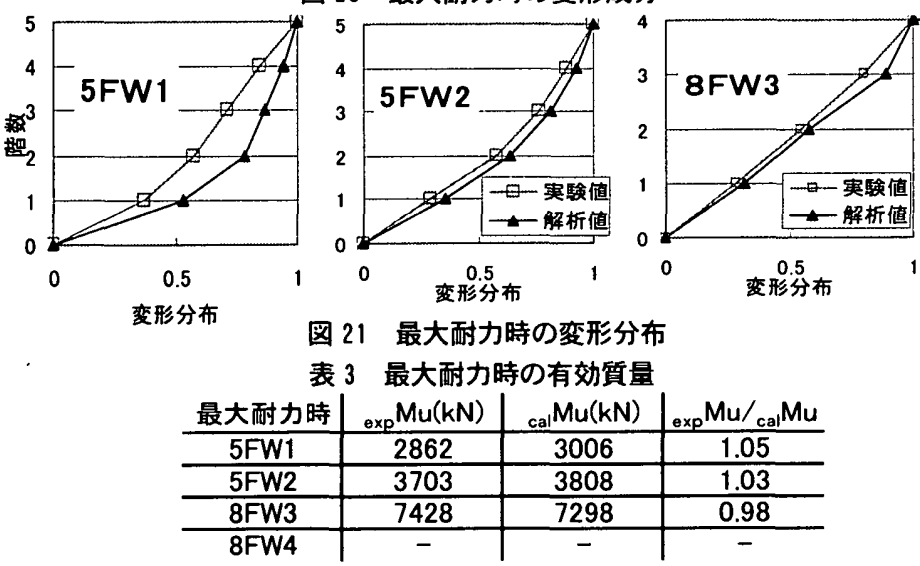

\section{4 安全限界時の变形分布の検討}

本検討では、安全限界時の変形分布について算定した。顕著な体 力低下が生じるまで加力が行われていないものについては、実験が 行われた最大変形時を安全限界時とした。変形分布の算定方法は 4.3 と同様である。図 22 に安全限界時の変形成分を、図 23 に変形分布 を示す。ここで、解析値は最大耐力時同様、梁の剛性を 0.25 に低下 させて算定している。図 22 より変形成分は、最大耐力時に比べて更 にせん断変形成分が増え、安全限界時においてはせん断変形が卓越 していることが分かる。また、変形分布は最大耐力時同様、どの実 験においても変形分布の解析值は実験值とほほ一致し、耐力壁のせ
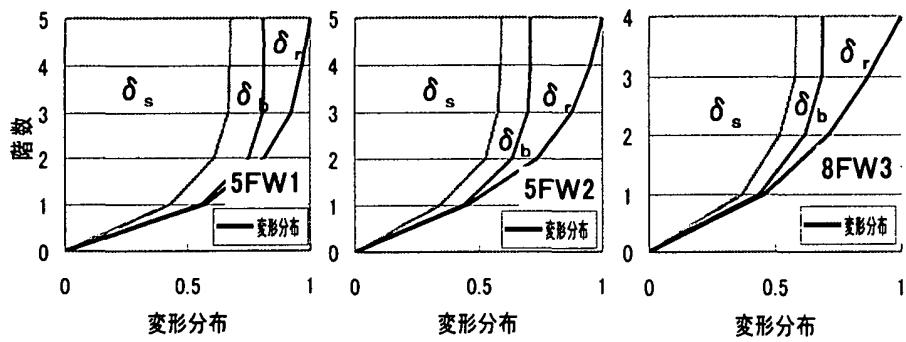

図 22 安全限界時の変形成分
断剛性及び梁の剛性を低下させる本方法でほほ塑性域の変形分布を 表すことが出来るといえる。表 4 に以上の変形分布を用いて算定し た有効質量を示す。表のように有効質量の実験值および解析值の差 は $4 \%$ 以内であり、そのことからも求めた変形分布が適切に評価され ていることが分かる。
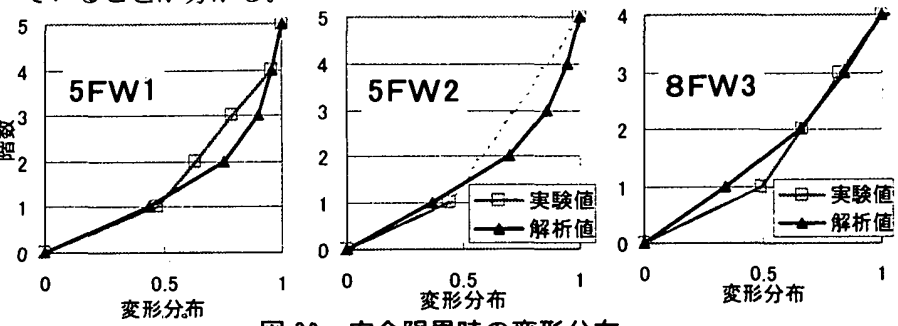

図 23 安全限界時の変形分布

表 4 安全限界時の有効質量

\begin{tabular}{c|c|c|c} 
安全限界時 & exp Mu(kN) $_{\text {cal Mu(kN) }}$ & exp Mu/cal Mu \\
\hline 5FW1 & 2950 & 2950 & 1.00 \\
\hline 5FW2 & 3887 & 3839 & 0.99 \\
\hline 8FW3 & 7845 & 7428 & 0.95 \\
\hline 8FW4 & - & - & -
\end{tabular}

6 結論

1 数少ない既往の実大実験での定常ループから、定常ループの特性 を検討し、1 サイクルしか繰り返されていない荷重履歴であって も、上側の半サイクルで定常ループの面積を想定しうる手法を提案 した。

2 壁式 RC 造の安全限界時近傍での減衰定数はおおむね $10 \%$ 以上で ある事を明らかにした。

3 壁式 $\mathrm{RC}$ 造の変形分布の算定を魚骨型モデルで簡便に行えることを 明らかにした。ただし、せん断変形だけでなく曲げ変形及びそれに よる回転変形を適切に考慮することが重要である。また、塑性域の 変形分布においても、壁のせん断剛性および梁の剛性を低下させる 簡便な算定方法を提案した。

\section{考文献}

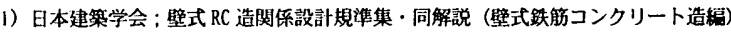

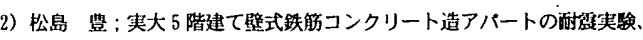

建設省建研究所年報、1969、pp37 43

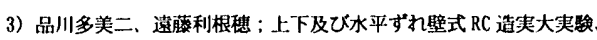

建設省建築研究所年報、1970、pp53 64

4）広沢雅也、山崎榕、小山義彦、荒木泰治、荒川総一郎；壁式 RC 造の高俤化を目的とした実

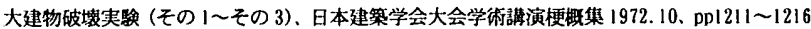
5）広沢雅也、口之町尚、後藤哲郎；8陵建壁式鉄筋コンクリート造アパートの耐掘性に関する

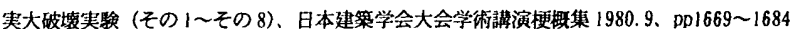
6）大場新太郎・鳥海勲；鉄筋コンクリート造低屏棈造物の振動特性、

日本建筑学会大会学術溝演梗概集 1973.10

7）国土交通省住宅局建筑指海課、国土交通省建築研究所、財用法人日本建築センター 社团法人建策研究振與協会編集；2001 年度版限界附力計算法の計算例とその解説 8）武藤清；而报部算法、1963

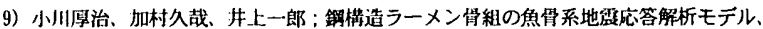
日本建策学会論文集、第 521 号、1999.7、pp119 126

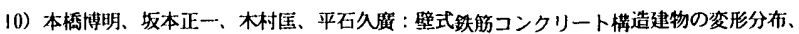

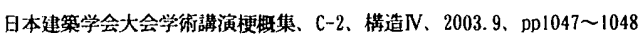

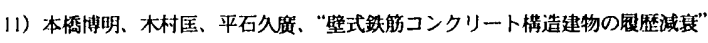

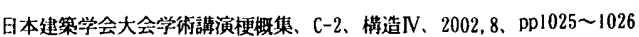

（2003年10月 10 日原稿受理，2003年12月12日採用決定） 